\title{
Constitutional Legal Responsibility of Local Government Employees in Sovereign Kyrgyzstan
}

\author{
Dzhamilia Asanbekova1* ${ }^{\circledR}$, Khanzada Karabaeva1, Kutman Ashimov², \\ Kanykei Nurmamat kyzy¹, Islam Abdyldaev3, Edil Begaliev', Omar Narbaev', \\ Salizhan Karimov ${ }^{4}$, Nurgul Atabekova ${ }^{5}$, Zhypargul Abdullaeva ${ }^{6 *}$ (i) \\ ${ }^{1}$ Department of Criminal Law and Procedure, Osh State University, Osh, Kyrgyzstan \\ ${ }^{2}$ Finance and Jurisprudence College, Osh State University, Osh, Kyrgyzstan \\ ${ }^{3}$ Department of Civil Law and Procedure, Osh State University, Osh, Kyrgyzstan \\ ${ }^{4}$ Department of History and Government Theory with Practice, Osh State University, Osh, Kyrgyzstan \\ ${ }^{5}$ Kyrgyz State Judicial University, Bishkek, Kyrgyzstan \\ ${ }^{6}$ Science and Research Department, Osh State University, Osh, Kyrgyzstan \\ Email: *jypar.science@oshsu.kg, *dasanbekova@oshsu.kg
}

How to cite this paper: Asanbekova, D., Karabaeva, K., Ashimov, K., Nurmamat kyzy, K., Abdyldaev, I., Begaliev, E., Narbaev, O., Karimov, S., Atabekova, N., \& Abdullaeva, Z. (2021). Constitutional Legal Responsibility of Local Government Employees in Sovereign Kyrgyzstan. Open Journal of Political Science, 11, 697-705. https://doi.org/10.4236/ojps.2021.114044

Received: September 7, 2021

Accepted: October 22, 2021

Published: October 25, 2021

Copyright $\odot 2021$ by author(s) and Scientific Research Publishing Inc. This work is licensed under the Creative Commons Attribution International License (CC BY 4.0).

http://creativecommons.org/licenses/by/4.0/

\begin{abstract}
The article considers local self-government institutions of constitutional responsibility. The authors analyze conditions for the effectiveness of constitutional and legal liability of local government employees in sovereign Kyrgyzstan. One of the important conditions for the effective functioning of local self-government in the Kyrgyz Republic is the legally established commitment of local government officials to the government, the population of the municipality, legal entities, including independent constitutional liability and individuals. Research methods in this work are based on historical events analysis.
\end{abstract}

\section{Keywords}

Local Self-Government, Constitutional And Legal Responsibility, Official Worker, Government Employees, Sovereign Kyrgyzstan, Social Politics, Social Self-Government

\section{Introduction}

Sovereignty establishment in Kyrgyzstan was initiated by constitutional legislation of Soviet Kyrgyzstan based on significant development and within the framework of the Soviet constitutional legislation as its component (Asanbekova 
et al., 2021). In the hierarchy of concepts "popular sovereignty", "National sovereignty", "government sovereignty" in the first place is popular sovereignty, which expresses the supreme, the inalienable right of the people to determine their destiny, to be the unique and independent bearer and spokesman for the supreme power in government and society (Abdykaimov \& Rakimbaev, 2014).

The legal basis of local self-government in the sovereign Kyrgyz Republic is implemented by the following laws and by-law acts: on April 9, 1990, the law "On the general principles of local self-government and the local economy in the USSR" (Electronic Fund Legal and Regulatory Technical Documents, 2021). The law consisted of only 27 articles and generally contained information on the origin and formation of local self-government.

On April 19, 1991, the Law "On Local Self-Government in the Kyrgyz Republic" was adopted. On March 4, 1992, the Jogorku Kenesh adopted a new version of the Law "On Local Self-Government and Local Government Administration in the Kyrgyz Republic" (Kyrgyz Republic Ministry of Justice, 2002a). This law is aimed at strengthening government power through the creation of local government administrations subordinate to the center.

The law provides for restrictions on the functions of state power and local self-government and abolishes the subordination of local authorities to councils at various levels. The Constitution of the Kyrgyz Republic, adopted on May 5, 1993, provides for local self-government. It includes a separate Chapter VII, entitled "Local Self-Government".

The Presidential Decree of September 22, 1994, approved the Regulation "On the Foundations of Local Self-Government in the Kyrgyz Republic", according to which the number of deputies of local councils was reduced from 21 thousand to 7 thousand.

On March 20, 1996, the Decree of the President of the Kyrgyz Republic "On measures to increase the role and responsibility of heads of local government administrations and local self-government bodies" was adopted (Kyrgyz Republic Ministry of Justice, 2002c). According to this decree, executive bodies 460 aiyl okmotu were established in villages and urban-type villages.

In 1997, a program of state support for local self-government and the main directions of local self-government reform was adopted. On July 8, 1998, a presidential decree approved the Regulation on the Election of the Mayor of Bishkek. The Concept of further development of local self-government in the Kyrgyz Republic for 1999-2001, approved by the Presidential Decree of August 2, 1999, was adopted.

On January 13, 2000, the Law of the Kyrgyz Republic "On the Status of Deputies of Local Councils” was adopted (Kyrgyz Republic Ministry of Justice, 1999). The Presidential Decree of January 17, 2001, approved the Provisional Regulation "On Pilot Elections of Heads of Local Self-Government Bodies of Villages and Towns Subordinated to the Districts of the Republic". Following this provision, elections of heads of several aiyl okmotu were held. 
Based on the results of the elections, a draft law "On Amendments and Addenda to the Election Code of the Kyrgyz Republic" was developed, which regulates the mechanism of direct election of heads of local self-government bodies by the population.

On May 2, 2001, by the Decree of the President of the Kyrgyz Republic "On the Fundamentals of Organization of Local Self-Government in Cities of the Kyrgyz Republic Subordinated to Oblasts", nine cities subordinated to oblasts were transferred to the principles of local self-government (Kyrgyz Republic Ministry of Justice, 2002a). On May 2, 2001, a presidential decree approved the Regulation on the People's Congress of Local Communities (Kyrgyz Republic Ministry of Justice, 2001).

On December 28, 2001, the Jogorku Kenesh of the Kyrgyz Republic adopted the Law "On Local Self-Government and Local Government Administrations". On March 15, 2002, the Law of the Kyrgyz Republic "On Municipal Property" was adopted (Kyrgyz Republic Ministry of Justice, 2020). On July 5, 2002, the Law of the Kyrgyz Republic "On Aksakal Courts" was adopted (Kyrgyz Republic Ministry of Justice, 2002b).

To develop and ensure the effectiveness and sustainability of local self-government in the Kyrgyz Republic until 2010, to increase the professionalism, initiative and responsibility of LSG staff, the President issued a decree on June 28, 2006. The main decree is "On the provision of municipal services and the main issues of its organization.” (Kyrgyz Republic Ministry of Justice, 2016b).

This decree registers political and administrative municipal services in the Kyrgyz Republic, and also "About the procedure for certification of municipal servants of the Kyrgyz Republic", "About the procedure for competition for administrative municipal service vacancies in the Kyrgyz Republic", "The procedure for assignment of class ranks About" regulations were approved. The Resolution of the Government of the Kyrgyz Republic of October 6, 2006, approved a standard agreement "On the village head" (Kyrgyz Republic Ministry of Justice, 2016a).

On October 23, 2007, the Constitutional Law of the Kyrgyz Republic "On Referendum" adopted (Kyrgyz Republic Ministry of Justice, 2016c). In 2008, the Law of the Kyrgyz Republic "On Local Self-Government and Local Government Administrations" was adopted. On July 14, 2011, the Law of the Kyrgyz Republic "On Elections of Deputies of Local Councils" was adopted.

On July 15, 2011, the Law of the Kyrgyz Republic "On Local Self-Government" was adopted. Legal norms reflecting the scope of public and municipal services are rarely found in national legislation.

Thus, the norms governing these issues are contained in the Law of the Kyrgyz Republic "On access to information held by state bodies and local self-government bodies" of December 28, 2006, No. 213, the Government of the Kyrgyz Republic of February 10, 2012, No. 85 On approval of the single register (list) of public services provided through structural subdivisions and subordinate institutions" 
and several other by-laws. Currently, Kyrgyzstan does not have a basic law regulating the standards and administrative procedures for the provision of municipal including public services.

\section{Services Providing by Local Self-Government in Sovereign Kyrgyzstan}

Article 96 in the Kyrgyz Republic Constitution states that the local government organs are responsible for government and its authorities in the observance and implementation of laws and responsible for the local communities' results of their activities (Sarykov, 2009). One of the most well-known principles of international law is the provision that public authorities and their officials, unlike citizens and other individuals who have the right to perform activities not prohibited by law, have the right to perform only those activities permitted by law.

At the same time, the authorities act within the competence established by law. Therefore, the competence of local self-government determines not only possible actions but also mandatory actions (Melichová \& Varecha, 2020), because the exercise of general power is not only a right but also a duty of the competent authorities.

Provision of government and municipal personal services are carried out at the request of the physical of them or legal entities in accordance with the administrative wasteful regulations and standards (Kail, 2011).

The competence of local self-government established by law and the solution of local issues through municipal legal regulation is to ensure the well-being of the population of the municipal system as a result of local self-government bodies' work. Thus, following the Law of the Kyrgyz Republic "On Local Self-Government", issues of local significance are determined based on the following principles:

1) Provide services with the lowest possible level of management that can effectively provide services;

2) To act effectively and purposefully in the implementation of functions and powers to ensure the quality of services provided;

3) Differentiation of functions and powers of local self-government bodies according to territorial, economic and other features;

4) Presence of local interests in the performance of functions and exercise of powers;

5) Harmonization of national and local interests;

6) Transparency and collegiality;

7) Limitation of functions and powers of state authorities and local self-government bodies in regulatory legal acts.

The above-mentioned law entrusts local self-government bodies entrusted with the following tasks:

1) Ensuring the economic development of the respective territory, as well as attracting investments and grants; 
2) Management of municipal property;

3) Formation, approval and execution of the local budget;

4) Provision of the population with clean water;

5) Ensuring the functioning of the sewerage system and treatment facilities in populated areas;

6) Maintenance of functioning of municipal roads in settlements;

7) Organization of lighting of public lands;

8) Ensuring the functioning of cemeteries and funeral services;

9) Creation of favorable conditions and landscaping of public lands;

10) Ensuring the functioning of parks, sports facilities and recreation areas;

11) Organization of collection, removal and recycling of household waste;

12) Maintenance of functioning of municipal transport and regulation of activity of public transport within settlements;

13) Protection of local cultural and historical sites;

14) Organization and maintenance of local libraries;

15) Establishment of rules of land cultivation and ensuring observance of norms and rules of town-planning, architectural works;

16) Placement of advertisements in the territory of the corresponding population in the order established by the legislation of the Kyrgyz Republic;

17) Assistance in maintaining public order;

18) Development of folk art;

19) Creation of conditions of rest;

20) Organization of activities to work with children and youth;

21) Ensuring conditions for the development of physical culture and mass sports;

22) Assistance in early warning of emergency situations and liquidation of their consequences.

In other words, local issues determine the scope of local self-government. However, it is not enough to specify the scope of work, it is necessary to determine the purpose of each problem, how to solve these problems (methods, tools), what results should be achieved. According to the law, it is obligatory to solve all issues of the municipal structure following the population needs and finance (Musaeva et al., 2021).

There is a practice of law enforcement, according to which local governments are obliged to address all local issues, but at the same time do not have the right to address several issues to reduce the volume of previously provided "services" of local significance. Thus, paragraph 2 of Article 113 of the Constitution of the Kyrgyz Republic, as well as the Law of the Kyrgyz Republic "On Local Self-Government" stipulates that certain state powers may be transferred to local self-government bodies.

In addition, the law stipulates that the transfer of government powers may be a one-time payment of targeted transfers from the national budget to the local budget or the identification of other sources of funding necessary for the transfer 
of government powers. Following the Law of the Kyrgyz Republic "On Local Self-Government", the main government powers to be transferred to a local self-government body include:

1) Development and implementation of employment and migration programs;

2) Registration of citizens, control over the implementation of the rules of the passport regime, registration and deregistration of citizens following the established procedure, compilation of voter lists;

3) Registration of civil acts by the legislation of the Kyrgyz Republic;

4 Provision of schools, buildings and other facilities for the provision of services in the field of preschool and vocational education and health care;

5) Carrying out notarial activities by the legislation of the Kyrgyz Republic;

6) Issuance to citizens of documents certifying identity, property and marital status and other documents provided by law;

7) To keep a primary record of conscripts and conscripts, to register and discharge them for military service, and to assist in their conscription;

8) Distribution and use of lands of the State fund of agriculture;

9) Generalization of materials on the further development of agricultural production, creation of economic forecasts on the production of agricultural products;

10) Assistance in veterinary and sanitary, anti-epizootic measures and selective breeding in animal husbandry;

11) To take appropriate measures to combat the trampling of crops and to protect forest belts and massifs;

12) collection of taxes, fees and insurance premiums;

13) development and implementation of measures to protect the environment;

14) protection of the rights of consumers;

15) heat supply of the corresponding territory;

16) Identification of low-income families to provide social assistance at the address;

17) Determination of the level of need for monthly benefits for low-income, large families in rural areas following the procedure established by the Government of the Kyrgyz Republic;

18) Other powers are established by law (Kyrgyz Republic Ministry of Justice, 2019).

However, in the absence of a functional analysis of the delegated powers, the transfer of state powers to local governments often does not take into account all the areas and measures required for their implementation, which leads to a decrease in the quality of municipal services and functions. In other words, there is no transfer of powers and no appropriate funding mechanism.

\section{Legal Basis for the Municipal Services Provision}

It is impossible to improve the quality of services provided without developing a 
regulatory framework governing the provision of municipal services (Chulkov, 2017).

Thus, to improve the quality of the services, it is necessary to do the following:

- Introduce a legal framework formation of a system of services providing through local governments;

- Approval of target programs to improve the quality of the municipal services;

- Development and approval of administrative regulations, instructions, methodical recommendations regulating the provision of services through local self-government bodies.

\section{Regulation and Standardization of Municipal Services}

Facilitating the provision of services depends primarily on the speed of resolution of the issue and how much time and effort it takes to communicate with the applicant authorities for this reason. In this regard, first, administrative regulations should be adopted everywhere. It is not a question of formal adoption of any document administrative regulations should set clear standards: terms of consideration of the issue, norms of waiting time in the queue, the order of interaction of various authorities. And most importantly, these rules must be followed: a system of strict measures and control over violations must be established. Second, an appropriate institutional, organized environment should be created, which will allow people to avoid running to different offices, especially when they are located in different parts of the city, and even in different settlements. Standardization is used to automate the relevant administrative processes, eliminating duplication of actions of employees, eliminating many conflicting instructions and management orders.

\section{Administrative Regulations as the Basic Element of Standardization}

Ensuring that the recipient of municipal services spends less time and other resources, reducing the number of actions and documents required from the recipient of services:

1) Approve dimensional parameters of requirements to quality and availability of municipal services;

2) Considering opinions and interests of recipients of municipal services.

Administrative regulations should be a document containing all the necessary information for both citizens and officials including term of service, list of documents, grounds for refusal, administrative procedures, procedure and responsibility for appealing against actions (or non-actions) of officials, contact information and more.

Optimization of the procedure for providing municipal services local selfgovernment bodies is subject to regulation of municipal services, inclusion in the relevant registers and optimization of their provision (Musaeva et al., 2020). A unified list of municipal services should be developed, which should be kept up 
to date and adjusted to changes in the regulatory framework. This list is the basis for planning, implementing and evaluating the effectiveness of measures to optimize municipal services. Optimization of the municipal services order provision should be carried out within the framework of sectoral optimization of municipal services and also about specific mass socially important municipal services. The practice of providing municipal services in Kyrgyzstan shows that today, due to the lack of generally accepted models of monitoring, the problem of building-integrated services to assess the effectiveness of public services is relevant.

\section{Conclusion}

Determining the quality of municipal services should take into account the two most important parameters such as the quality of the content of its final result and the quality of service available to the consumer. At the same time, these parameters should be clearly stated in administrative regulations and standards of municipal services and should form the basis for the formation of a system of regulatory requirements for the quality, accessibility and convenience of public services.

In addition, it is necessary to independently consider the issue of payment for services provided in the implementation of measures to optimize the provision of municipal services. To prevent the receipt of payments not provided for in regulations, it is necessary to make appropriate changes, abandon or transfer payments and take measures to streamline the collection of fees from applicants for municipal services. It is also necessary to provide training for municipal employees on the work on optimization of municipal functions, administrative procedures and the development of administrative regulations at the local level.

\section{Conflicts of Interest}

The authors declare no conflicts of interest regarding the publication of this paper.

\section{References}

Abdykaimov, E. D., \& Rakimbaev, E. N. (2014). Constitutional and Legal Aspects of Strengthening the Sovereignty of the People of Kyrgyzstan. Society and Law, 4, 318-321.

Asanbekova, D., Osmonova, A., Abdyldaev, I., Begaliev, E., Ashimov, K., Kyzy, K., Narbaev, O., Karimov, S., \& Abdullaeva, Z. (2021). Political System in the Sovereign Kyrgyzstan. Open Journal of Political Science, 11, 266-272. https://doi.org/10.4236/ojps.2021.112018

Chulkov, A. S. (2017). Improving the Quality of State and Municipal Services and Ways to Optimize the Network of Institutions That Provide Them. Finance and Credit, 23, 143-159. https://doi.org/10.24891/fc.23.3.143

Electronic Fund Legal and Regulatory Technical Documents (2021). On the General Principles of Local Self-Government and Local Economy in the USSR. https://docs.cntd.ru/document/901817750 
Kail, J. Ya. (2011). Provision of State and Municipal Services in the Russian Federation: State, Problems, Prospects. Regional Economics: Theory and Practice, No. 28, 48-55.

Kyrgyz Republic Ministry of Justice (1999). Development Concept of Local Self-Government in the Kyrgyz Republic for 1999-2001.

http://cbd.minjust.gov.kg/act/view/ru-ru/3187?cl=ru-ru

Kyrgyz Republic Ministry of Justice (2001). Decree of the Kyrgyz Republic President on Measures to Enhance the Role of the People Kurultay Representatives of Local Communities of the Kyrgyz Republic in the Management of Local Affairs. http://cbd.minjust.gov.kg/act/view/ru-ru/2152

Kyrgyz Republic Ministry of Justice (2002a). About Local Self-Government and Local State Administration in the Republic of Kyrgyzstan.

http://cbd.minjust.gov.kg/act/view/ru-ru/878?cl=ru-ru

Kyrgyz Republic Ministry of Justice (2002b). Kyrgyz Republic Law on Aksakal Courts. http://cbd.minjust.gov.kg/act/view/ru-ru/1070/10?cl=ru-ru

Kyrgyz Republic Ministry of Justice (2002c). Decree of the Kyrgyz Republic President "On Measures to Enhance the Role and Responsibility of Heads Local State Administrations and Local Self-Government”. http://cbd.minjust.gov.kg/act/view/ru-ru/46440

Kyrgyz Republic Ministry of Justice (2016a). Model Agreement "On the Village Head". http://cbd.minjust.gov.kg/act/view/ru-ru/57873?cl=ru-ru

Kyrgyz Republic Ministry of Justice (2016b). On the Main Issues of the Provision and Organization of Municipal Services in the Kyrgyz Republic.

http://cbd.minjust.gov.kg/act/view/ru-ru/4488

Kyrgyz Republic Ministry of Justice (2016c). Constitutional Law of the Kyrgyz Republic “On Referendum”. http://cbd.minjust.gov.kg/act/view/ru-ru/202193?cl=ru-ru

Kyrgyz Republic Ministry of Justice (2019). About Local Self-Government. http://cbd.minjust.gov.kg/act/view/ru-ru/203102

Kyrgyz Republic Ministry of Justice (2020). About Municipal Ownership on Property. http://cbd.minjust.gov.kg/act/view/ru-ru/992

Melichová, K., \& Varecha, L. (2020). Endogenous Political, Institutional, Cultural, and Geographic Determinants of Intermunicipal Cooperation-Evidence from Slovakia. Sustainability, 12, Article No. 709. https://doi.org/10.3390/su12020709

Musaeva, A., Rita, S., Karimova, K., \& Abdullaeva, Z. (2021). Qualimetric Assessment of the Public Services Efficiency Provision in the Kyrgyz Republic. Open Journal of Political Science, 11, 123-133. https://doi.org/10.4236/ojps.2021.111008

Musaeva, A., Salmorbekova, R., Rustamova, D., \& Abdullaeva, Z. (2020). Social Qualimetry of Public Services Standardization in the Kyrgyz Republic. Advances in Applied Sociology, 10, 348-355. https://doi.org/10.4236/aasoci.2020.109021

Sarykov, K. T. (2009). Responsibility of Local Self-Government Bodies and Their Officials to the Population (Based on Materials from the Kyrgyz Republic). Actual Problems of Russian Law, No. 21, 551-555. 